ISAHP 2001, Berne, Switzerland, August 2-4, 2001

\title{
A'WOT: INTEGRATING THE AHP WITH SWOT ANALYSIS
}

\author{
Jyrki Kangas, Mauno Pesonen, Mikko Kurttila, Miika Kajanus \\ Finnish Forest Research Institute \\ Kannus Research Station \\ P.O.Box 44, FIN-69101 Kannus, Finland \\ jyrki.kangas@metla.fi
}

Keywords: AHP, A'WOT, natural resource management, strategic planning, SWOT

\begin{abstract}
Summary: SWOT is a widely applied tool in strategic decision support. In SWOT, the internal and external factors most important for the enterprise's future are grouped into four categories: Strengths, Weaknesses, Opportunities, and Threats. By applying SWOT in a strategic planning process, the aim usually is to develop and adopt a strategy resulting in a good fit between these internal and external factors. However, SWOT includes no means of analytically determining the importance of factors or of assessing the fit between SWOT factors and decision alternatives. In A'WOT, the Analytic Hierarchy Process (AHP) and its eigenvalue calculation framework are integrated with SWOT analysis. The aim in applying the hybrid method is to improve the quantitative information basis of strategic planning processes. AHP's connection to SWOT yields analytically-determined priorities for the factors included in SWOT analysis and makes them commensurable. In addition, decision alternatives can be evaluated with respect to each SWOT factor by applying the AHP. So, SWOT provides the basic frame within which to perform an analysis of the decision situation, and the AHP assists in carrying out SWOT more analytically and in elaborating the analysis so that alternative strategic decisions can be prioritised.
\end{abstract}

\section{Introduction}

SWOT (the acronym standing for Strengths, Weaknesses, Opportunities and Threats) is a widely applied tool in the analysis of internal and external environments in order to achieve a systematic approach and support for strategic decision situations (see, e.g., Wheelen and Hunger, 1995, Hill and Westbrook, 1997). The internal and external factors most important for the enterprise's future are referred to as strategic factors. In SWOT these factors (called SWOT factors) are grouped into four categories called SWOT groups: strengths, weaknesses, opportunities, and threats. By applying SWOT in a strategic planning process, the aim usually is to develop and adopt a strategy resulting in a good fit between the internal and external factors. SWOT can also be used when a strategy alternative suddenly emerges and the decision context relevant to it has to be analysed.

When used properly, SWOT can provide a good basis for strategy formulation. However, SWOT could be used more efficiently than normally has been the case in its applications (McDonald, 1993). When using SWOT, analysis lacks the possibility of comprehensively appraising the strategic decision making situation. It easily remains at the level of only pinpointing the factors. In addition, the expression of individual factors is often of a very general nature and brief (Hill and Westbrook, 1997). Furthermore, SWOT includes no means of analytically determining the importance of the factors or of assessing the decision alternatives with respect to the factors. The further utilisation of SWOT alone is, thus, mainly based on the qualitative analysis made in the planning process, and on the capabilities and expertise of the persons participating in the process. All in all, the result of SWOT analysis is too often only a listing or an incomplete qualitative examination of internal and external factors. This is why it has sometimes been referred to as "So WOT".

The idea in utilizing the AHP (Saaty, 1977,1980) within a SWOT framework is to systematically evaluate the SWOT factors and make them commensurable as regards their intensities (Kurttila et al., 2000). The AHP's qualities can be regarded to be valuable characteristics in SWOT analysis. Additional value from a SWOT analysis can be achieved by performing pairwise comparisons between the SWOT factors and then analysing them by means of the eigenvalue technique as applied in the AHP. SWOT provides the basic frame within 
which to perform an analysis of the decision situation and AHP assists in carrying out SWOT more analytically. The hybrid method is called A'WOT.

After carrying out the comparisons, useful quantitative information can be obtained about the decision making situation. On grounds of the comparisons of the SWOT factors and groups it can be analysed, for example, whether there is a specific weakness requiring most of the attention, or if the company is expected to be faced with future threats exceeding the company's combined opportunities (Kurttila et al., 2000). In addition, using A'WOT enables choice alternatives to be evaluated with respect to each SWOT factor and to each SWOT group (Pesonen et al., 2000). When the importance of different SWOT groups has also been determined, the choice alternatives can be prioritised with respect to the strategic choice situation as a whole.

\section{Steps of the hybrid method $A^{\prime}$ WOT}

The hybrid method A'WOT proceeds as follows:

(i) The SWOT analysis is carried out. The relevant factors of the external and internal environment are identified and included in SWOT analysis.

(ii) Pairwise comparisons between the SWOT factors are carried out separately within each SWOT group. When making the comparisons, the issue at stake is which of the two factors compared is more important and how much more important. With these comparisons as the input, the mutual priorities of the factors are computed.

(iii) The mutual importance of the SWOT groups are determined. There are several possibilities as to how to do this. For example, the factor with the highest priority may be chosen from each group, and these four factors are then compared pairwise and their relative priorities are calculated on the basis of the comparisons. After that, the other factors are scaled relatively to these priority values within each group. Another possibility is to directly compare the importance of the entire groups. In addition to these two simplest ways, more complicated procedures can be applied, if desired.

(iv) The strategy alternatives are evaluated with respect to each SWOT factor as in the AHP.

(v) Global priorities can now be calculated for the strategy alternatives in accordance with the general A'WOT decision hierarchy, presented in Figure 1.

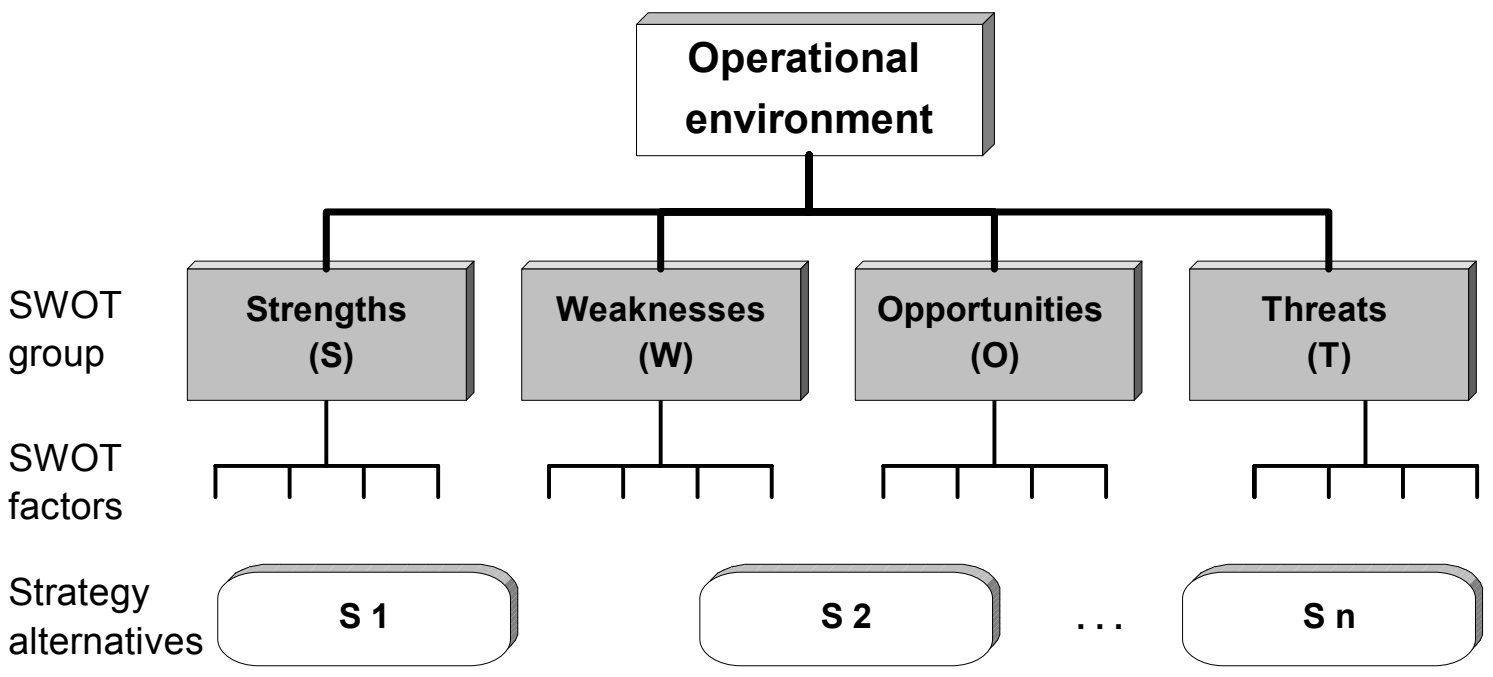

Figure 1. The hierarchical presentation of $A^{\prime}$ WOT analysis.

As an extension of the analysis, a level of scenarios can be added to the decision hierarchy, consisting of different future states-of-nature. This being the case, the probabilities for the scenarios to take place can be assessed, and the importance of SWOT factors and groups can be estimated separately for each scenario. When 
calculating the global priorities, the probabilities of the scenarios occuring are then applied as weights in the analysis.

In the earliest A'WOT applications (see Kurttila et al., 2000, Pesonen et al., 2000) only the steps (i), (ii), and (iii), as listed above, were carried out. Indeed, in the phases of strategic planning processes typically approached by using SWOT, the most immediate aim is not always to compare alternative strategic decisions. Instead, SWOT is often applied only in the analysis of internal and external factors of the operational environment where the decisions have to be implemented, i.e., in an early stage of a strategic planning process. A'WOT strengthens the decision basis also in the case where the result is only the quantification and commensuration of SWOT factors.

However, the final goal of any strategic planning process as a whole is to develop and adopt a strategy resulting in a good fit between internal and external factors. When the steps (iv) and (v) are included in the A'WOT process, the initial SWOT analysis might not always be applicable as such. The reason for this is that the SWOT factors could have been formulated so that strategy alternatives can not be evaluated with respect to them. This being the case, SWOT factors need some value-focused modification and fine-tuning (by the consultant). For A'WOT, SWOT factors should be determined by asking which are the internal and external factors of the operational environment that should be taken into account in choosing the strategy for the enterprise. Then it is possible to compare strategy alternatives with respect to strengths, weaknesses, opportunities, and threaths as listed in SWOT. To take an example of the pairwise comparisons: which of the two strategy alternatives compared (when implemented) makes it possible to better exploit a certain opportunity, and how much better?

The very first A'WOT study, published in a peer-reviewed journal, dealt with the development of SWOT analysis connected to a decision situation of whether or not to adopt a forest-certification system in a rural enterprise having forestry as one line of business (Kurttila et al., 2000). The analysis included in-depth and critical examination of internal and external factors (Figure 2), but not any analytical prioritising of strategic decision alternatives. The idea was, that it is not sufficient just to collect the relevant factors. Moreover, managers must view these factors thoroughly and identify the foremost internal factors, which may be called critical success factors. In the case study, the results indicated that certification could be considered to be a potential strategy alternative and that it could be used as a competitive advantage on the enterprise. It was also found out that the A'WOT experiment increased and improved the information basis of the strategic planning process compared to that obtained by using the ordinary SWOT only. Making pairwise comparisons forced the decision maker to think over the weights of the factors and to analyse the situation more precisely and in more depth.

Also in the case of developing the investment strategy for a Finnish forest industry company UPM Kymmene Ltd in North America (Pesonen et al., 2000) only the steps (i), (ii), and (iii), were performed, and the analysis of the operational decision environment was made based on them (Table 1).

\section{An application of A'WOT: Prioritising natural resource management strategies at the Finnish Forest and Park Service}

The Finnish Forest and Park Service (FFPS) is a State enterprise entrusted with the administration of most of the State-owned natural resources in Finland. About a quarter of the country's land area, some 8.7 million hectares, is under FFPS's management. Of this, about 2.7 million hectares are national parks and corresponding protected areas. About 3.2 million hectares are managed for commercial forestry purposes.

The FFPS practices strategic natural resource planning at the regional level. The resulting natural resource plans are aimed to cover different land use class allocations, the multiple objectives of different interest groups, and to secure social, ecological and economic sustainability (Heinonen et al., 1997). The most important outputs of the planning process are the strategic management plan (referred to as natural resource plan) and corresponding land-use maps for the area under planning. 


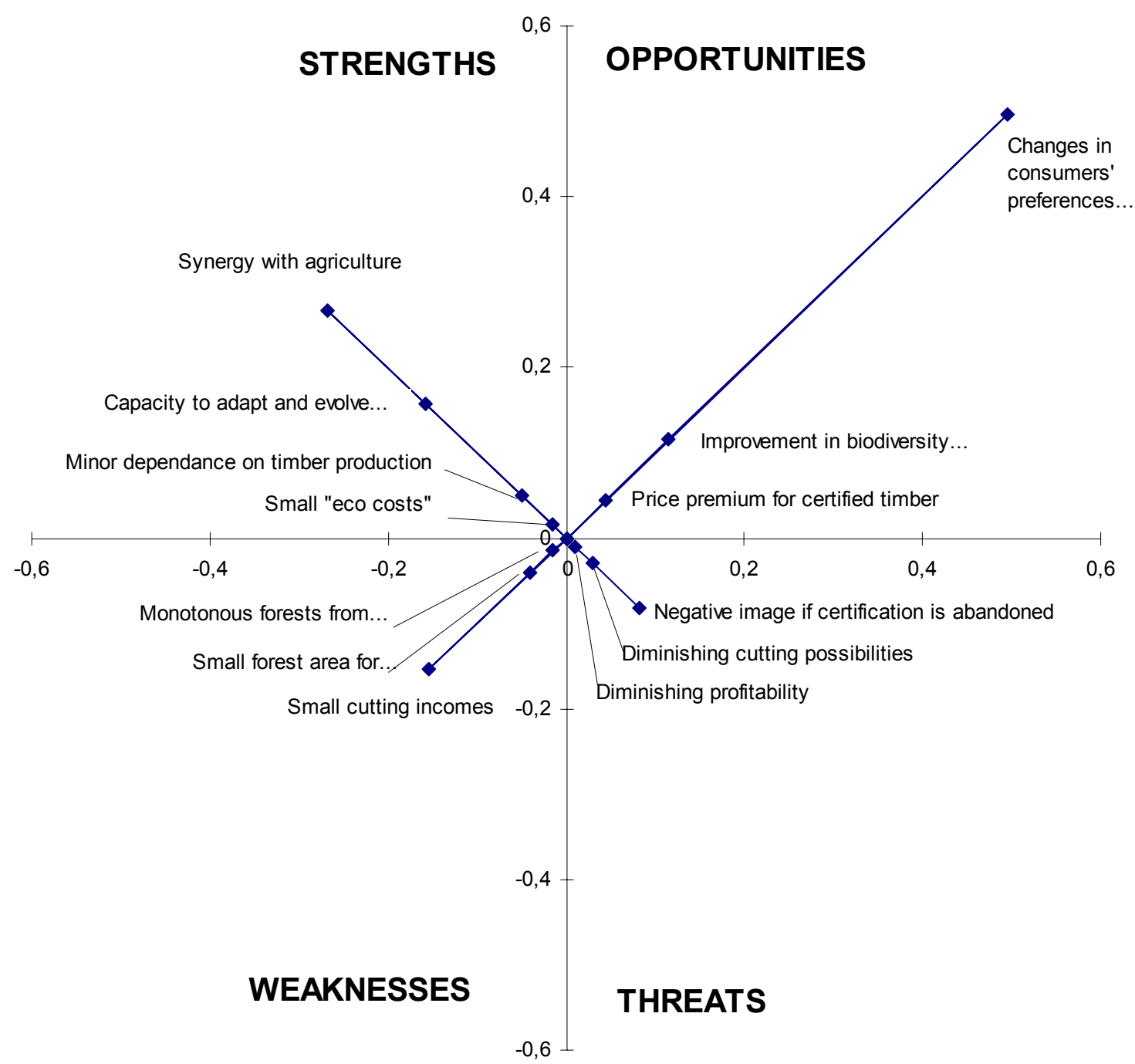

Figure 2. An illustration of the relative importance of SWOT factors in an A'WOT application to a forestcertication case (Kurttila et al., 2000).

The strategic planning process of the FFPS typically includes an analysis of the present state of natural resources, a SWOT analysis, definitions of criteria and indicators of sustainability, an analysis of the objectives of different interest groups, the production of alternative strategies and the assessment of their overall priority. In the SWOT analysis, the natural resources and their utilisation possibilities are studied from the viewpoints of both economic, ecological and social sustainability. Not surprisingly, there have been difficulties in linking the SWOT results with the other phases of the natural resource planning process. In particular, their utilisation has been found to be problematic when evaluating alternative strategies.

The A'WOT was applied in the FFPS's natural resource planning area of Western Finland, covering the southeastern quarter of Finland. About 60 percent of the country's population is in this region, and economic activities are concentrated there. The FFPS owns about 5 percent $(423,700 \mathrm{ha})$ of the region's forestry land, with nonindustrial private forest ownership predominant with 78 percent ownership. Although forestry and wood production are the FFPS's core business areas in Western Finland, also recreation and nature conservation are emphasized. Sixty-three percent of the region's forestry land is categorized as being mainly used for forestry. A fairly considerable proportion, 29 percent, is reserved for nature protection. 
Table 1. Priorities of the SWOT groups and factors, and consistency ratios ${ }^{1}$ of comparisons, in the case of developing the investment strategy of Finnish forest industries in North America (the factor having the greatest weight in each SWOT group is underlined) (Pesonen et al., 2000).

\begin{tabular}{|c|c|c|c|c|c|}
\hline SWOT group & $\begin{array}{l}\text { Group } \\
\text { priority }\end{array}$ & SWOT factors & $\begin{array}{l}\text { Consist } \\
\text { ency } \\
\text { ratio }\end{array}$ & $\begin{array}{l}\text { Priority of } \\
\text { factor within } \\
\text { group }\end{array}$ & $\begin{array}{l}\text { Overall } \\
\text { priority of } \\
\text { factor }\end{array}$ \\
\hline \multirow[t]{8}{*}{ Strengths } & \multirow[t]{8}{*}{0.223} & Finnish cost efficiency & \multirow{8}{*}{0.080} & 0.134 & 0.030 \\
\hline & & Credibility & & 0.034 & 0.008 \\
\hline & & Finnish know-how & & 0.218 & 0.049 \\
\hline & & Finnish production technology & & $\underline{0.231}$ & $\underline{0.052}$ \\
\hline & & Availability and price of timber & & 0.072 & 0.016 \\
\hline & & Structure of capital resources & & 0.042 & 0.009 \\
\hline & & Existing own marketing organization & & 0.203 & 0.045 \\
\hline & & Finnish environmental know-how & & 0.063 & 0.014 \\
\hline \multirow[t]{5}{*}{ Weaknesses } & \multirow[t]{5}{*}{0.143} & Labor and energy prices & \multirow{5}{*}{0.102} & 0.045 & 0.006 \\
\hline & & $\begin{array}{l}\text { Weak decision premises }->\text { problems in } \\
\text { evaluating returns }\end{array}$ & & 0.325 & 0.046 \\
\hline & & $\underline{\text { Management skills }}$ & & $\underline{0.378}$ & $\underline{0.054}$ \\
\hline & & Local process know-how & & 0.070 & 0.010 \\
\hline & & Large investments needed & & 0.181 & 0.026 \\
\hline \multirow[t]{7}{*}{ Opportunities } & \multirow[t]{7}{*}{0.545} & Customers and markets close by & \multirow{7}{*}{0.173} & $\underline{0.278}$ & $\underline{0.152}$ \\
\hline & & Shifting of know-how & & 0.082 & 0.045 \\
\hline & & USA net importer of certain paper grades & & 0.143 & 0.078 \\
\hline & & Increasing credibility and recognition & & 0.176 & 0.096 \\
\hline & & Global customers more readily reachable & & 0.111 & 0.060 \\
\hline & & $\begin{array}{l}\text { Stabilizing changes in economic trends and } \\
\text { exchange rates }\end{array}$ & & 0.097 & 0.053 \\
\hline & & Investment gap & & 0.112 & 0.061 \\
\hline \multirow[t]{8}{*}{ Threats } & \multirow[t]{8}{*}{0.088} & Possible trade war & \multirow{8}{*}{0.103} & 0.044 & 0.004 \\
\hline & & Cultural differences (at management level) & & 0.090 & 0.008 \\
\hline & & USA's legislation & & 0.054 & 0.005 \\
\hline & & Environmental attitudes in USA & & 0.114 & 0.010 \\
\hline & & $\underline{\text { Customer-producer engagement }}$ & & $\underline{0.268}$ & $\underline{0.024}$ \\
\hline & & Inflexible labor use (at certain mills) & & 0.110 & 0.010 \\
\hline & & Negative attitudes towards forest industries & & 0.071 & 0.006 \\
\hline & & $\begin{array}{l}\text { Insufficient understanding of local } \\
\text { customers }\end{array}$ & & 0.247 & 0.022 \\
\hline
\end{tabular}

\footnotetext{
${ }^{1}$ The consistency ratio of the comparisons between four SWOT groups was 0.123 .

During the FFPS's natural resource planning process in Western Finland SWOT analysis was carried out separately by three business units at the FFPS (Forestry, Recreation, and Nature Protection) and with respect to three dimensions of sustainability (economic, social and ecological) (Heinonen et al., 1997). For the purposes of the A'WOT experiment, SWOT was slightly compacted by both combining and removing some SWOT factors.

Four alternative strategies were produced during the planning process. Each of the aforementioned business units at the FFPS created a strategy fulfilling the strategic land use objectives. The alternatives produced were Forestry Strategy (powerful emphasis on sustainable economic use of forests), Recreation Strategy (emphasis on the recreational use of forests and social and economic sustainability), and Protection Strategy (emphasis on nature protection and ecological sustainability). In addition, a strategy following the current land allocation and forestry principles, called Basic Strategy, was formulated. All these alternatives were produced in such a way that they could be considered practically feasible. The main differences between these alternatives were caused by land use allocation principles (e.g. between forestry areas, protected and recreational areas and areas having
} 
specific environmental values) and the permitted treatments specified for these areas (Table 2). These four strategies were taken under closer examination in order to clarify their fit with regard to the operational environment.

Having completed these phases, the priorities of the SWOT factors and the fit of the alternative strategies subject to these factors were estimated by pairwise comparisons following the steps presented above. When the weights of the business units were determined, Forestry got the weight of 0.5 , and Recreation and Nature Protection both got the weight of 0.25 .

Table 2. The outcomes of alternative strategies (Pesonen et al., 2001b).

\begin{tabular}{lcccc}
\hline & $\begin{array}{c}\text { FORESTRY } \\
\text { strategy }\end{array}$ & $\begin{array}{c}\text { RECREATION } \\
\text { strategy }\end{array}$ & $\begin{array}{c}\text { PROTECTION } \\
\text { strategy }\end{array}$ & $\begin{array}{c}\text { BASIC } \\
\text { strategy }\end{array}$ \\
\hline Net income (mill. FIM/year) & 109 & 93 & 77 & 101 \\
Commercial forest area (1000 ha) & 232 & 216 & 163 & 231 \\
Cutting volume (1000 m 3 /year) & 882 & 814 & 648 & 860 \\
Labor input in forestry (working years) & 130 & 108 & 86 & 120 \\
Forests age $>$ 60 years (1000 ha) & 93 & 111 & 112 & 103 \\
Forests age $>100$ years (1000 ha) & 25 & 32 & 33 & 30 \\
Recreation index & 5,74 & 6,62 & 6,39 & 6,17 \\
Volume of dead wood (1000 $\mathrm{m}^{3}$ ) & 52 & 47 & 56 & 47 \\
Protected areas (1000 ha) & 37 & 37 & 58 & 37 \\
Forests with specific natural values (ha) & 6500 & 21400 & 53800 & 6500 \\
\hline
\end{tabular}

The opportunities had the greatest weight according to all the business units. However, in the Nature Protection business unit, threats got the same weight as opportunities, and also weaknesses were more predominant there than in the other business units (Table 3). Among the most important internal factors there were both strengths (know-how, land and water property) and a couple weaknesses (lack of information concerning biodiversity due to insufficient planning resources, and the age and development class structure of the forests). New planning techniques and new recreational areas were emphasized among the opportunities. The foremost threat was lack of resources, i.e. the possibility for cuts in funding. The overall weights of alternative strategies revealed that the Recreation Strategy obtained the highest priority, followed by the Protection Strategy (Figure 3). In the business units of Forestry and Recreation, the Recreation Strategy was the most preferred, but in the business unit Nature Protection, the Protection Strategy achieved the highest global priority.

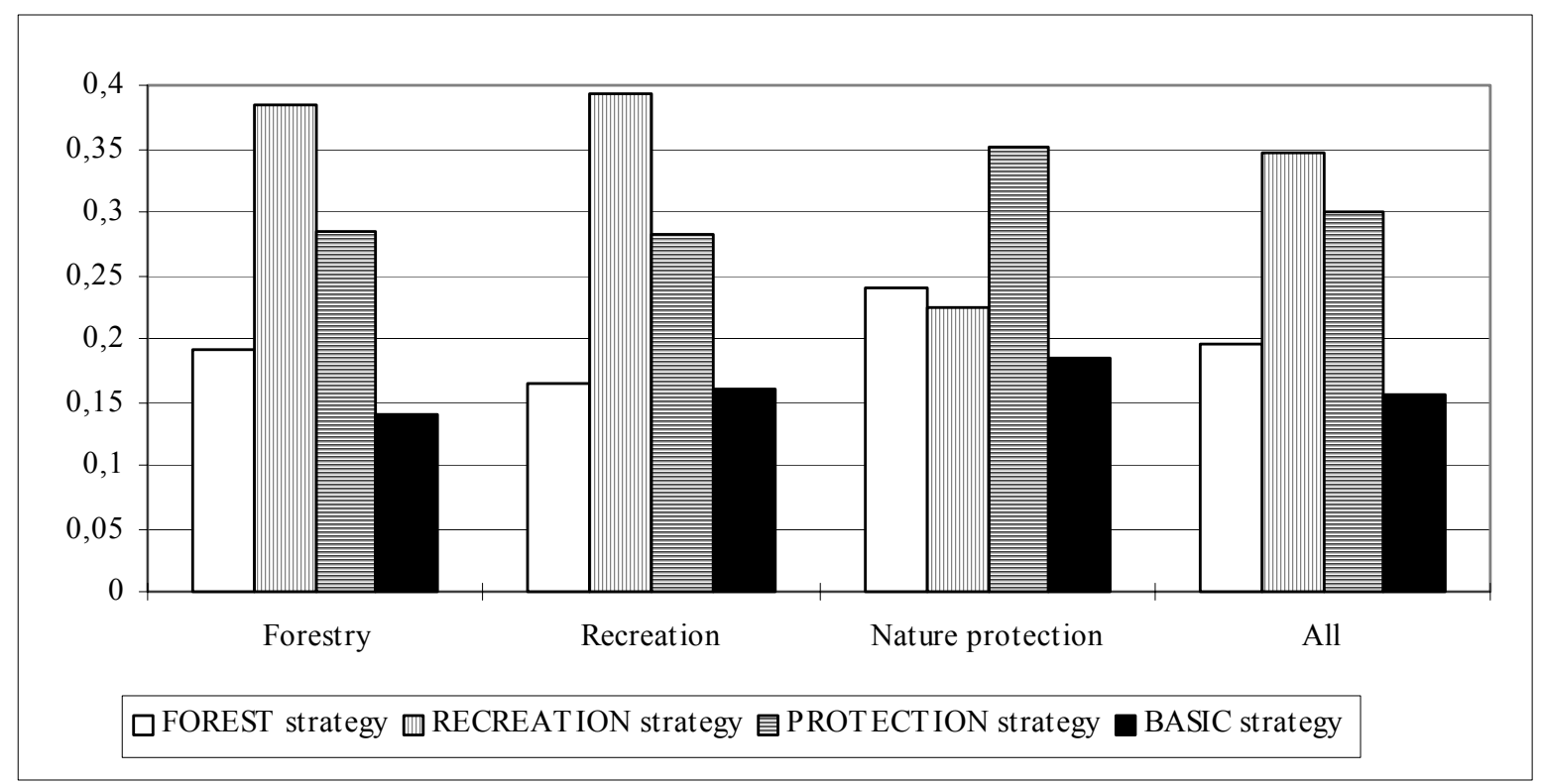

Figure 3. The overall priorities of alternative strategies by FFPS's different business units (Forestry, Recreation, and Nature Protection) and by weighting the business units (All) (Pesonen et al. 2001b). 
The choice of strategy was perhaps due to the principles followed in the preparation of the four alternative strategies compared. Perhaps the economic dimension of sustainability was over-emphasized in the Forestry Strategy so that even the Forestry business unit did not find it to be the best of the compared strategies. One reason for this was that, when producing alternative strategies to be further evaluated, clearly different strategies were aimed at. However, within the Forestry business unit, also recreational and conservation aims were given considerable weight in actual decision making - more than was the case with the Forestry Strategy.

On the other hand, when preparing the Recreation Strategy, cutting incomes and other wood-production objectives, and the jobs they offer for local inhabitants, were seen as important elements of social sustainability. Thus, in fact, the Recreation Strategy was some kind of a compromise solution between the requirements of the economic and social dimensions of sustainability. In all the strategies, the basic principles of ecological sustainability were respected. So, no strategy was clearly unsustainable in the sense of ecological considerations. However, in the Protection Strategy, environmental aspects had an especially high priority.

For more details of the application, see Pesonen et al. (2001).

Table 3. The compressed SWOT analysis of FPS's natural resource planning process in Western Finland and priorities of the SWOT factors and groups (Pesonen et al. 2001b).

\begin{tabular}{|c|c|c|c|c|}
\hline $\begin{array}{l}\text { SWOT } \\
\text { Groups }\end{array}$ & $\begin{array}{l}\text { Business } \\
\text { unit }\end{array}$ & $\begin{array}{l}\text { Local } \\
\text { priority }\end{array}$ & SWOT-factors & $\begin{array}{l}\text { Local } \\
\text { priorities }\end{array}$ \\
\hline \multirow[t]{14}{*}{ Strengths } & \multirow[t]{5}{*}{ Forestry } & \multirow[t]{5}{*}{0.200} & - benefits from large-scale forestry & 0.074 \\
\hline & & & - organizational efficiency and long customer relations & 0.301 \\
\hline & & & - versatile interest groups & 0.169 \\
\hline & & & - versatile know-how & 0.338 \\
\hline & & & - protected areas and wilderness areas & 0.118 \\
\hline & \multirow[t]{4}{*}{ Recreation } & \multirow[t]{4}{*}{0.180} & - large land and water property & 0.374 \\
\hline & & & - areas for sportfishing & 0.089 \\
\hline & & & - hiking areas & 0.291 \\
\hline & & & - game (epecially forest grouse and moose) & 0.245 \\
\hline & \multirow{5}{*}{$\begin{array}{l}\text { Nature } \\
\text { protection }\end{array}$} & \multirow[t]{5}{*}{0.113} & - regional policy importance, e.g. as an employer & 0.117 \\
\hline & & & - landscape ecological planning & 0.395 \\
\hline & & & - participatory planning & 0.257 \\
\hline & & & - many attractive recreation areas & 0.078 \\
\hline & & & - good knowledge from the areas & 0.153 \\
\hline \multirow[t]{16}{*}{ Weaknesses } & \multirow[t]{5}{*}{ Forestry } & \multirow[t]{5}{*}{0.078} & - contradictory objectives and political control & 0.208 \\
\hline & & & - infertile growing sites & 0.061 \\
\hline & & & - age and development class structures of forests & 0.177 \\
\hline & & & - internal cooperation poor & 0.102 \\
\hline & & & $\begin{array}{l}\text { - negative image and historical burden (e.g. practised efficient, } \\
\text { timber production oriented forestry) }\end{array}$ & 0.452 \\
\hline & \multirow[t]{6}{*}{ Recreation } & \multirow[t]{6}{*}{0.160} & - infertile growing sites & 0.110 \\
\hline & & & - age and development class structures of forests (not many old & 0.401 \\
\hline & & & forests) & 0.203 \\
\hline & & & - operations at large areas increase costs, e.g. at waste disposal & 0.182 \\
\hline & & & - recreational areas at outlying districts & 0.104 \\
\hline & & & $\begin{array}{l}\text { - not many suitable areas for hunting of waterfowl and field } \\
\text { game }\end{array}$ & \\
\hline & \multirow{5}{*}{$\begin{array}{l}\text { Nature } \\
\text { protection }\end{array}$} & \multirow[t]{5}{*}{0.277} & - lacking information concerning biodiversity due to insufficient & 0.549 \\
\hline & & & planning resources & 0.090 \\
\hline & & & - fragmented areas & 0.131 \\
\hline & & & $\begin{array}{l}\text { - excessive organizational fractionizing (internal cooperation } \\
\text { poor) }\end{array}$ & 0.230 \\
\hline & & & - long practised efficient, timber production oriented forestry & \\
\hline \multirow[t]{5}{*}{ Opportunities } & \multirow[t]{5}{*}{ Forestry } & \multirow[t]{5}{*}{0.522} & $\begin{array}{l}\text { - new planning methods (natural resource planning, landscape } \\
\text { ecological planning, participatory planning) }\end{array}$ & 0.332 \\
\hline & & & - improvement in profitability and effectiviness & 0.061 \\
\hline & & & - original and multi-objective forestry & 0.188 \\
\hline & & & - broad domestic and international importance & 0.136 \\
\hline & & & - communication and marketing & 0.282 \\
\hline
\end{tabular}




\begin{tabular}{|c|c|c|c|c|}
\hline & Recreation & 0.577 & $\begin{array}{l}\text { - "multiple use model area": customers due to diverseness and } \\
\text { game }\end{array}$ & $\begin{array}{l}0.302 \\
0.336\end{array}$ \\
\hline & & & - new recreational areas & 0.110 \\
\hline & & & - nature protection areas & 0.174 \\
\hline & & & - concentration of operations & 0.078 \\
\hline & & & - a lot of young forests: good future & \\
\hline & Nature & 0.305 & - multi-objective forestry & 0.103 \\
\hline & protection & & - increase in the level of biodiversity & 0.141 \\
\hline & & & - "forest continents" and acquisition of new areas & 0.235 \\
\hline & & & $\begin{array}{l}\text { - new planning methods (natural resource planning, landscape } \\
\text { ecological planning. Participatory planning) }\end{array}$ & 0.103 \\
\hline & & & - resources & 0.417 \\
\hline Threats & Forestry & 0.200 & - decrease in the area of usable forests & 0.362 \\
\hline & & & - economic pressures for the utilization of forests & 0.103 \\
\hline & & & - organizational incoherence of FPS & 0.232 \\
\hline & & & $\begin{array}{l}\text { - decreasing timber sales incomes (development of price level, } \\
\text { decreasing amounts of sold wood, increasing harvesting costs) }\end{array}$ & 0.123 \\
\hline & & & - homogenization of forest nature & 0.180 \\
\hline & Recreation & 0.083 & $\begin{array}{l}\text { - under-estimation of the meaning of commercial forests (their } \\
\text { ownership changes from FPS to outsider) }\end{array}$ & 0.320 \\
\hline & & & - run out of old forests & 0.144 \\
\hline & & & $\begin{array}{l}\text { - wear and tear, hullaballoos and unpleasantness have negative } \\
\text { influence to users of recreational and protected areas }\end{array}$ & 0.392 \\
\hline & & & - decline in the amount of forest grouses & 0.144 \\
\hline & Nature & 0.305 & - decrease in the area of FPS's forests & 0.148 \\
\hline & protection & & - lack of resources: staff and funds & 0.565 \\
\hline & & & - economic pressures concerning the utilization of FPS's forests & 0.148 \\
\hline & & & - utilization of non-renewable natural resources & 0.065 \\
\hline & & & $\begin{array}{l}\text { - "timber production organization" does not pay attention to the } \\
\text { natural values }\end{array}$ & 0.074 \\
\hline
\end{tabular}

\section{Discussion and conclusion}

According to the experiences of A'WOT applications and tests, the combined use of the AHP and SWOT analysis is a promising approach in supporting strategic decision-making processes (Hobbs, Hytönen and Kangas, 2001, Kurttila et al., 2000, Pesonen et al., 2000, Pesonen et al., 2001a, 2001b). Making pairwise comparisons forces the decision-makers to think over the weights of the SWOT factors and to analyse the situation more precisely and in more depth than the standard SWOT does.

So far, A'WOT applications are few. However, the approach is suitable for nearly all decision situations where SWOT has been seen applicable. By using A'WOT, not only the mutual weighting of SWOT factors, but also the evaluation of alternative strategic decisions can be integrated with ordinary SWOT analyses. Thus, perhaps the most crucial weakness of SWOT can be avoided by making use of the AHP within SWOT; as is done when the full version of A'WOT is applied. In addition to operational environment, decision makers' goals are crucial in the strategic choice situations. It is likely that A'WOT could be improved in the future by including more explicitly the different objectives into the analyses (i.e. not only by means of SWOT factors).

Although the AHP has been a popular tool in multi-criteria decision making, many authors have been critical of the original methodology. Perhaps, the two foremost problems - being crucial ones also with A'WOT - have been that the original comparison scale does not allow expressing any hesitation regarding the single comparisons, and that the AHP itself does not provide tools for deep enough analyses of the comparisons, particularly of the uncertainty inherent in the data. However, the basic idea of performing pairwise comparisons, as being an pedagogical and intuitive approach, has proved to be practicable. This advantage has been noted in A'WOT applications, too.

Other, "statistically sounder" techniques than that used in the standard AHP have been proposed for analysing uncertainties in pairwise comparisons (e.g., De Jong, 1984, Alho, Kangas and Kolehmainen, 1996, Alho and 
Kangas, 1997, Kangas et al., 1998). Also developments in the measurement scales applied in comparisons have been presented (e.g., Leskinen and Kangas, 1998, Leskinen, 2000). These techniques might also be used in the approach based on the combined use of SWOT and the AHP (see, e.g., Hobbs, Hytönen and Kangas, 2001). For example, a regression version of the AHP formulated in Bayesian terms (Alho and Kangas, 1997) enables A'WOT analyses so that not all the pairwise comparisons need to be performed. Thus, relatively great number of SWOT factors could be included in analyses. If desired, also other modes of questioning than pairwise comparisons, and corresponding calculation techniques, might be applied within A'WOT.

One approach to dealing with the uncertainties involved in the assessment of future development might be the application of scenario modeling. In this approach, each possible future scenario would have its own SWOT analysis and AHP comparisons. Appraising the probabilities to scenarios and weighting the SWOT factors with them could yield a more comprehensive picture of the effects of the various future outcomes. Weihrich (1982), too, proposed a dynamic SWOT analysis, where changes in internal and external factors are compared over time.

It can be concluded that the A'WOT, a hybrid method of AHP and SWOT, can be applied for increasing and improving the information basis of strategic planning processes. It provides not only a solid decision support but also an effective framework for learning in strategic decision support in numerous situations. It can also be used as a tool in communication and education in decision making processes where multiple decision makers or judges are involved. In addition, making separate A'WOTs for individuals or interest groups can provide a good basis for studying differences in opinions, expectations etc. of different stakeholders, related to a certain decision-making process (Hobbs, Hytönen and Kangas, 2001).

\section{References}

Alho, J.M. and Kangas, J. (1997), Analyzing uncertainties in experts' opinions of forest plan performances. Forest Science, 43, 521-528.

Alho, J. M., Kangas, J. and Kolehmainen, O. (1996), Uncertainty in Expert Predictions of the Ecological Consequences of Forest Plans. Applied Statistics, 45, 1-14.

De Jong, P. (1984), A statistical approach to Saaty's scaling method for priorities. Journal of Mathematical Psychology, 28, 467-478.

Heinonen, P., Hallila, H.,. Koivurinne, J., Oikarinen, A., Saarikoski, O., Salmi, O., Soinne, H. and Tanninen T. (1997), Länsi-Suomen alueen luonnonvarasuunnitelma. Metsähallituksen metsätalouden julkaisuja 12. (In Finnish). 112 p.

Hill, T. and Westbrook, R. (1997), SWOT analysis: It's Time for a Product Recall. Long Range Planning, $30(1), 46-52$.

Hobbs, M., Hytönen, L. and Kangas, J. (2001), Factors affecting the economic sustainability of the nonindustrial private forest enterprise: a comparison of stakeholder perceptions. In: Väyrynen, J. \& Niskanen, A. (eds.). International Symposium on Economic Sustainablity of Small-scale Forestry. IUFRO Working Unit 3.08.00: Small-scale Forestry. 20-26 March, 2001, Joensuu, Finland. Abstracts. p. 60 .

Kangas, J., Alho, J., Kolehmainen, O. and Mononen, A. (1998), Analyzing consistency of experts' judgments Case of assessing forest biodiversity. Forest Science, 44, 610-617.

Kotler, P. (1988), Marketing Management: Analysis, Planning, Implementation and Control. Sixth edition. Prentice-Hall International Edition. 776 p.

Kurttila, M., Pesonen, M., Kangas, J. and Kajanus, M. (2000), Utilizing the analytical hierarchy process (AHP) in SWOT analysis - A hybrid method and its application to a forest-certification case. Forest Policy and Economics, 1, 41-52.

Leskinen P. (2000), Measurement scales and scale independence in the Analytic Hierarchy Process. Journal of Multi-Criteria Decision Analysis, 9, 163-174.

Leskinen, P. and Kangas, J. (1998), Analysing uncertainties of interval judgment data in multiple-criteria evaluation of forest plans. Silva Fennica, 32, 363-372.

McDonald, M. H. B. (1993), The Marketing Planner. Butterworth-Heinemann, Oxford. 143 p.

Pesonen, M., Ahola, J., Kurttila, M., Kajanus, M. and Kangas, J. (2000), Investment strategies of Finnish forest industry in North America: A case study using A'WOT. In: Munn, I., Bullard, S. H., Grado, S. C. \& Grebner, D. L. (eds.). SOFEW '99. Southern Forest Economics Workshop. April 18-20. Biloxi, MS. Proceedings of the 1999, 43-49. 
Pesonen, M., Kangas, J., Kurttila, M. and Kajanus, M. (2001a), Applying A'WOT to choose a management strategy for the forest holding owned by private partnership. In: Väyrynen, J. \& Niskanen, A. (eds.). International Symposium on Economic Sustainablity of Small-scale Forestry. IUFRO Working Unit 3.08.00: Small-scale Forestry. 20-26 March, 2001, Joensuu, Finland. Abstracts. p. 79.

Pesonen, M., Kurttila, M., Kangas, J., Kajanus, M. and Heinonen, P. (2001b), Assessing the priorities among resource management strategies at the Finnish Forest and Park Service. To appear in Forest Science.

Saaty, T. L. (1977), A scaling method for priorities in hierarchical structures. Journal of Mathematical Psychology, 15, 234-281.

Saaty, T. L. (1980), The Analytic Hierarchy Process, McGraw-Hill, New York. 287 p.

Weihrich, H. (1982), The TOWS Matrix: A Tool for Situational Analysis. Long Range Planning, 15(2), 54 - 66.

Wheelen, T. L. and Hunger, J. D. (1995), Strategic Management and Business Policy, $5^{\text {th }}$ Edition, Addison Wesley, Reading, MA. 